\title{
Kineococcus marinus sp. nov., isolated from marine sediment of the coast of Jeju, Korea
}

\author{
Soon Dong Lee
}

Correspondence

Soon Dong Lee

sdlee@cheju.ac.kr
Department of Science Education, Cheju National University, Jeju 690-756, Republic of Korea

A novel marine actinomycete, designated strain $\mathrm{KST} 3-3^{\top}$, which was isolated from a sediment sample of the coast of Jeju, Korea, was subjected to a polyphasic taxonomic characterization. The organism was characterized morphologically by the formation of motile, coccoid cells. A phylogenetic analysis based on $16 \mathrm{~S}$ rRNA gene sequence comparisons showed that the organism was related to the genera Kineosporia and Kineococcus, and members of the suborder Frankineae, and occupied the deepest branch outside a taxon encompassing members of the genus Kineococcus. The organism showed relatively low levels of $16 \mathrm{~S}$ rRNA gene sequence similarity to members of the genera Kineococcus (93.0-93.4\%) and Kineosporia (93.1-93.8\%). The morphological and chemotaxonomic characteristics, albeit with a slightly higher level of sequence similarity to members of the genus Kineosporia, supported its classification within the genus Kineococcus. On the basis of the polyphasic data presented, it was evident that the organism should be assigned to a novel species of the genus Kineococcus, for which the name Kineococcus marinus sp. nov. is proposed. The type strain is strain KST3-3 ${ }^{\top}\left(=\mathrm{KCCM} 42250^{\top}=\mathrm{NRRL}\right.$ B-24439 ${ }^{\top}$.
The genus Kineococcus was proposed by Yokota et al. (1993) to accommodate an aerobic, Gram-positive, motile, coccus-shaped bacterium; Kineococcus aurantiacus was characterized chemotaxonomically by the presence of meso-diaminopimelic acid, arabinose and galactose in the cell wall, MK- $9\left(\mathrm{H}_{2}\right)$ as the predominant menaquinone, diphosphatidylglycerol and phosphatidylglycerol in the polar lipid profile, 12-methyltetradecanoic acid as a major cellular fatty acid and a DNA G + C content of $73.9 \mathrm{~mol} \%$. The genus currently comprises two species, Kineococcus aurantiacus (Yokota et al., 1993) and Kineococcus radiotolerans (Phillips et al., 2002), which were isolated from a soil sample and a radioactive working area, respectively. Phylogenetically, it was shown that members of the genus were closely related to the genus Kineosporia within the Actinobacteria based on 16S rRNA gene sequence analyses (Phillips et al., 2002).

During investigations into the genetic diversity of polysaccharide-producing marine bacteria from the coast of the island of Jeju, Republic of Korea, strain KST3-3 ${ }^{\mathrm{T}}$ was isolated from a sand beach sediment and subject to morphological, cultural, physiological and chemotaxonomic characterization in addition to phylogenetic analysis based on 16S rRNA gene sequence studies. It was evident from the polyphasic evidence that the organism could be

The GenBank/EMBL/DDBJ accession number for the 16S rRNA gene sequence of strain KST3-3 ${ }^{\top}$ is DQ200982. readily differentiated from the two recognized species of the genus Kineococcus.

Beach sediment samples were taken at a depth of $1 \mathrm{~m}$ below the surface and placed directly into sterilized $50 \mathrm{ml}$ Falcon tubes. For bacterial isolation, each sediment sample $(1 \mathrm{~g})$ was placed into a sterile plastic tube containing $9 \mathrm{ml}$ sterile distilled water, which was then mixed in a tube rotator for $30 \mathrm{~min}$ at moderate speed. Aliquots $(100 \mu \mathrm{l})$ of the serial diluent of the samples were transferred onto SC-SW agar plates, supplemented with $60 \%(\mathrm{v} / \mathrm{v})$ sterilized natural seawater. The isolation medium (SC-SW) consisted of $1 \%$ soluble starch, $0.03 \%$ casein, $0.2 \% \mathrm{KNO}_{3}, 0.2 \% \mathrm{NaCl}$, $0.002 \% \mathrm{CaCO}_{3}, 1.8 \%$ agar, $0.005 \% \mathrm{MgSO}_{4} .7 \mathrm{H}_{2} \mathrm{O}$ and $0 \cdot 001 \% \mathrm{FeSO}_{4} .7 \mathrm{H}_{2} \mathrm{O}$ in a $60: 40$ mixture of natural seawater and distilled water. The plates were incubated at $30{ }^{\circ} \mathrm{C}$ for 14 days, and colonies were subcultured on YE-SW medium $(0.4 \%$ yeast extract, $1.0 \%$ malt extract, $0.4 \%$ glucose and $1.8 \%$ agar in a 60:40 mixture of natural seawater and distilled water); pure cultures were maintained as $20 \%$ glycerol suspensions at -20 and $-70^{\circ} \mathrm{C}$.

Colony pigmentation was observed visually and recorded after 5 days growth at $30^{\circ} \mathrm{C}$ on YE-SW agar. Cell morphology and motility were observed by using an Olympus light microscope equipped with phase-contrast optics (magnification $\times 400$ ). Cells were grown for 3 days at $30{ }^{\circ} \mathrm{C}$ on YE-SW agar and suspensions were made in sterile saline for microscopic examination. For scanning electron microscopy, bacterial samples were dehydrated through a graded series of ethanol or a mixture of ethanol and isoamyl 
acetate, then critical-point-dried with $\mathrm{CO}_{2}$. Sputter-coated specimens were examined in a Hitachi S-2600 scanning electron microscope. Cell motility was confirmed by the presence of flagella when observed by transmission electron microscope. Cells of strain KST3-3 $3^{\mathrm{T}}$ were strictly aerobic, motile, non-spore-forming, Gram-positive cocci. The cells occurred singly, in pairs or in clusters (Fig. 1). On most solid growth media, the strain formed capsular polysaccharide-like substances; this was confirmed by negative staining with India ink. Colonies were circular, smooth, convex and deep orange in colour.

Chromosomal DNA for phylogenetic characterization was extracted and purified by using the Wizard genomic DNA purification kit (Promega) according to the manufacturer's instructions. The $16 \mathrm{~S}$ rRNA gene of the chromosomal DNA was amplified by PCR with primers 27f (5'-AGAGTTTGATCMTGGCTCAG- $\left.{ }^{\prime}\right)$ and $1492 \mathrm{r}$

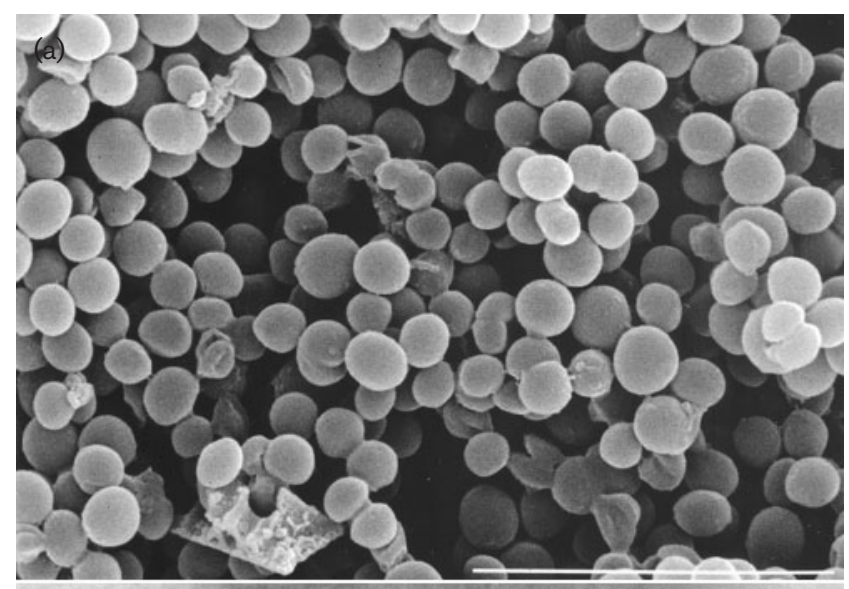

(b)

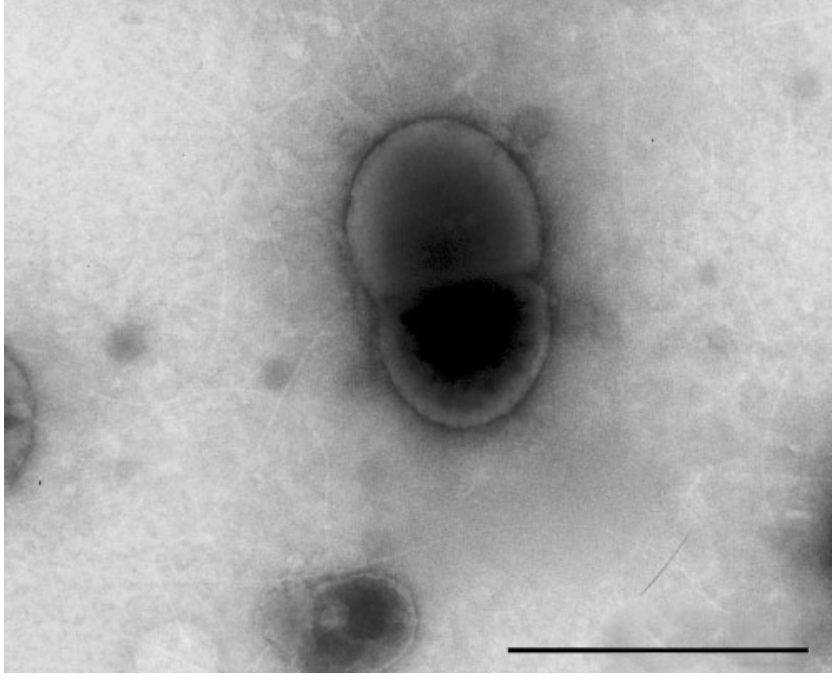

Fig. 1. Electron microscopy of strain $K S T 3-3^{\top}$ grown on YE$\mathrm{SW}$ agar for 3 days at $30^{\circ} \mathrm{C}$. (a) Scanning electron micrograph of cells. Bar, $5 \mu \mathrm{m}$. (b) Transmission electron micrograph of cells. Bar, $1 \mu \mathrm{m}$.
(5'-TACGGYTACCTTGTTACGACTT-3') as described by Lee et al. (2000). After purification, the resultant PCR product was directly sequenced using an ABI PRISM BigDye Terminator cycle sequencing kit (Applied Biosystems) and an automatic DNA sequencer (model 3730xl; Applied Biosystems). The sequence determined was aligned with the corresponding sequences of representatives of the genus Kineococcus and related genera by using the CLUSTAL X program (Thompson et al., 1997) and was then manually optimized according to the secondary structure of the $16 \mathrm{~S}$ rRNA gene of Escherichia coli (Brosius et al., 1978). Phylogenetic analyses were performed using three tree-making algorithms, the neighbour-joining (Saitou \& Nei, 1987), maximum-likelihood (Felsenstein, 1981) and maximumparsimony (Fitch, 1971) methods. A phylogenetic tree was reconstructed with the neighbour-joining method from evolutionary distances calculated using the method described by Jukes \& Cantor (1969). Reliability of the tree topology was evaluated by using the SEQBOOT, DNADIST, NEIGHBOR and CONSENSE programs in the PHYLIP package (Felsenstein, 1993), based on 1000 bootstrapped trees generated.

The almost complete 16S rRNA gene sequence of strain KST3-3 $3^{\mathrm{T}}$, comprising a continuous stretch of $1406 \mathrm{nt}$, was determined and compared with those of representatives of the suborder Frankineae and the genera Kineococcus and Kineosporia. A total of 1268 unambiguous aligned positions present in all strains between positions 72 and 1452 (E. coli numbering system) were used for phylogenetic analysis. Nocardia asteroides was used as an outgroup taxon for tree construction. A phylogenetic tree (Fig. 2), based on $16 \mathrm{~S}$ rRNA gene sequence comparisons, showed that strain KST3 $-3^{T}$ was loosely related to members of the genera Kineosporia and Kineococcus, and formed the deepest branch outside a taxon encompassing members of the genus Kineococcus. The phylogenetic relationship was supported by a low bootstrap value of $45 \%$. The organism showed $16 \mathrm{~S}$ rRNA gene sequence similarity values of $93 \cdot 0-93 \cdot 4 \%$ to members of the genus Kineococcus, and slightly higher values to members of the genus Kineosporia $(93 \cdot 1-93 \cdot 8 \%)$. By contrast, the $16 \mathrm{~S}$ rRNA gene sequence similarity value between Kineococcus aurantiacus and Kineococcus radiotolerans was $98.9 \%$, a value considerably higher than that (93\%) reported previously (Phillips et al., 2002). To date, the taxonomic status of the genera Kineococcus and Kineosporia remains uncertain at the hierarchical classification structure above the family level. It was shown from our phylogenetic analyses (Fig. 2) that members of these genera were phylogenetically related to members of the suborder Frankineae (Stackebrandt et al., 1997).

For chemotaxonomic characterization, strain $\mathrm{KST} 3-3^{\mathrm{T}}$ was cultivated on YE-SW broth for 3 days at $30^{\circ} \mathrm{C}$ and harvested by centrifugation at 3000 r.p.m. for $20 \mathrm{~min}$. Cell biomass was washed twice with distilled water and freeze-dried. The isomer of diaminopimelic acid and acyl type of the cell wall and sugar composition of whole-cell hydrolysates were 


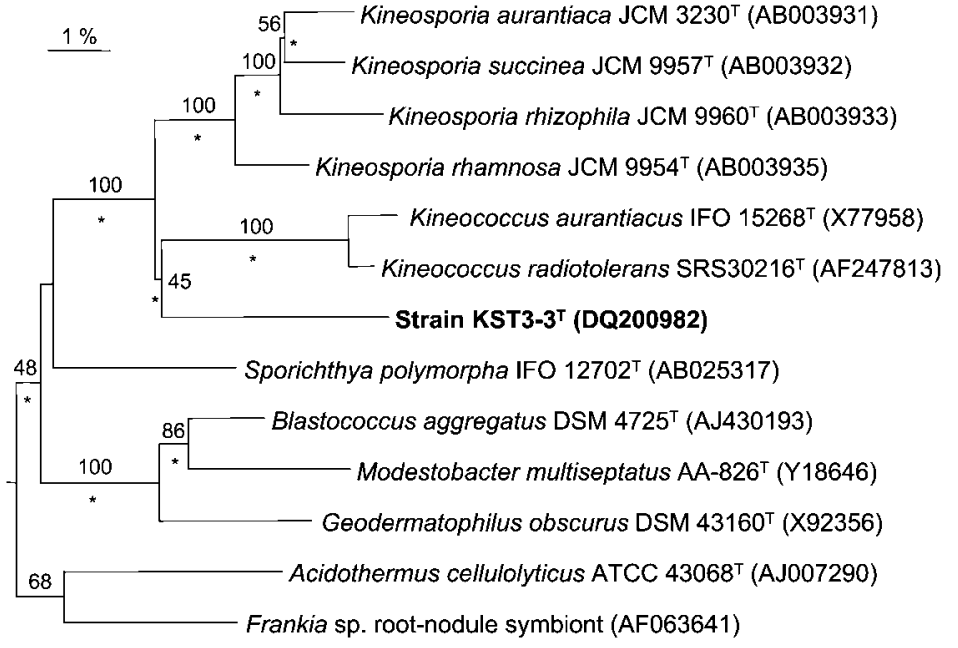

Fig. 2. Phylogenetic tree derived from $16 \mathrm{~S}$ rRNA gene sequences showing the relationship of strain KST3-3 ${ }^{T}$ with members of the genera Kineococcus and Kineosporia, and representatives of the suborder Frankineae. The tree was reconstructed by using the neighbour-joining method from evolutionary distances calculated using the Jukes-Cantor coefficient. Nocardia asteroides was used as an outgroup taxon (not shown). Asterisks indicate branches of the tree that were also recovered using both maximum-likelihood (Felsenstein, 1981) and maximum-parsimony (Fitch, 1971) tree-making algorithms. Numbers at nodes indicate percentages of bootstrap support based on a neighbourjoining analysis of 1000 resampled datasets (only values $>40 \%$ are indicated). Bar, 1 substitution per $100 \mathrm{nt}$. analysed according to the methods of Staneck \& Roberts (1974), Uchida \& Aida (1984) and Saddler et al. (1991). Polar lipids were extracted according to the small-scale method of Minnikin et al. (1984). Purified menaquinones were identified by HPLC (Kroppenstedt, 1985). The phospholipid composition was determined by the method of Minnikin et al. (1977) and analysis of mycolic acids was performed according to the method of Minnikin et al. (1980). Extraction of cellular fatty acids and determination of the fatty acid compositions were by GC according to the instructions of the Microbial Identification System (MIDI). The test strain was grown for 3 days at $30^{\circ} \mathrm{C}$ on trypticase soy broth agar. The $\mathrm{G}+\mathrm{C}$ content of the DNA was determined by HPLC (Mesbah et al., 1989).

The results of chemical analyses are given in the species description below, indicating that the organism has chemotaxonomic markers typical for members of the genus Kineococcus (Yokota et al., 1993). The fatty acid profile of strain KST3-3 ${ }^{\mathrm{T}}$ was represented by the predominance of anteiso- $\mathrm{C}_{15: 0}(54 \cdot 4 \%)$ and $\mathrm{C}_{16: 0}(7 \cdot 5 \%)$. Other cellular fatty acids detected as minor components were $\mathrm{C}_{12: 0}(2 \cdot 9 \%)$, iso- $\mathrm{C}_{15: 0}(1 \cdot 3 \%), \mathrm{C}_{15: 0}(2 \cdot 6 \%)$, iso- $\mathrm{C}_{16: 1}$ $\mathrm{H}(2 \cdot 3 \%)$, iso- $\mathrm{C}_{16: 0}(2.9 \%)$, anteiso- $\mathrm{C}_{17: 1} \omega 9 \mathrm{c}(1 \cdot 8 \%)$, anteiso- $\mathrm{C}_{17: 0}(4 \cdot 4 \%), \mathrm{C}_{17: 1} \omega 8 c(3 \cdot 6 \%), \mathrm{C}_{17: 0}(1 \cdot 7 \%)$, $\mathrm{C}_{18: 1} \omega 9 c(2 \cdot 1 \%), \mathrm{C}_{18: 0}(3 \cdot 7 \%)$ and 10-methyl $\mathrm{C}_{18: 0}$ $(2 \cdot 1 \%)$, in addition to a mixture of $\mathrm{C}_{16: 1} \omega 7 c$ and/or iso- $\mathrm{C}_{15: 0} 2-\mathrm{OH}(2 \cdot 7 \%)$. Thus, strain $\mathrm{KST} 3-3^{\mathrm{T}}$ showed a considerable difference in the relative amount of anteiso$\mathrm{C}_{15: 0}$ from the type strains of Kineococcus aurantiacus and Kineococcus radiotolerans (Phillips et al., 2002; Yokota et al., 1993), although the fatty acid profile of Kineococcus aurantiacus was determined under analytical conditions different from those described above. The $\mathrm{G}+\mathrm{C}$ content of strain KST3-3 $3^{\mathrm{T}}$ was $76 \cdot 6 \mathrm{~mol} \%$, a value slightly higher than that reported for Kineococcus aurantiacus $(73 \cdot 3 \mathrm{~mol} \%$; Yokota et al., 1993).
Decomposition of adenine, hypoxanthine, DL-tyrosine and xanthine was examined as described by Gordon et al. (1974). The temperature for growth was tested at 4, 10, 20, 30, 37, 40 and $45^{\circ} \mathrm{C}$. $\mathrm{NaCl}$ tolerance was studied on yeast extract-malt extract agar (ISP medium 2) containing $\mathrm{NaCl}$ at final concentrations of $1-9 \%(\mathrm{w} / \mathrm{v})$. Nitrate reduction and hydrolysis of casein, gelatin and starch were examined by using the methods of MacFaddin (1980). The production of hydrogen sulfide was detected on trypticase soy broth (Difco) by using lead acetate strips. Catalase activity was determined with a $3 \%(\mathrm{v} / \mathrm{v})$ hydrogen peroxide solution. Urease activity was determined by a colour change in Bacto urea broth (Difco). The ability to use a variety of substrates as sole carbon sources was tested using GP2 microplates of the Microlog system (Biolog), containing 95 substrates. Cells were grown for 3 days at $30^{\circ} \mathrm{C}$ on YE-SW agar and suspended in $2 \%(\mathrm{w} / \mathrm{v})$ sea salts solution (Sigma). Aliquots of $150 \mu \mathrm{l}$ of the suspension were transferred to each well and the plates were incubated for $48 \mathrm{~h}$ at $30^{\circ} \mathrm{C}$. Reduction of the tetrazolium dye was determined by measuring the absorbance at $595 \mathrm{~nm}$ using a microplate reader.

Results of the physiological characterization are given in the species description below. Cells were aerobic, oxidasenegative and catalase-positive and showed growth at $4-37^{\circ} \mathrm{C}$ and $\mathrm{pH} 5 \cdot 1-10 \cdot 1$. No growth was observed at or above $40^{\circ} \mathrm{C}$. Strain $\mathrm{KST} 3-3^{\mathrm{T}}$ was readily differentiated from members of the genus Kineococcus on the basis of an array of physiological properties (Table 1).

In conclusion, the relatively low levels of $16 \mathrm{~S}$ rRNA gene sequence similarity between strain $\mathrm{KST} 3-3^{\mathrm{T}}$ and related genera of the class Actinobacteria suggest that the organism merits novel generic status. However, the phylogenetic joining of strain KST3-3 $3^{\mathrm{T}}$ to a clade encompassing members of the genus Kineococcus was strongly supported by morphological characteristics (motile, coccoid-shaped cells) and chemotaxonomic characters (e.g. principal 
Table 1. Differential characteristics of strain $\mathrm{KST} 3-3^{\top}$ and type strains of the genus Kineococcus

Strains: 1, strain KST3-3 $3^{\mathrm{T}}$; 2, Kineococcus aurantiacus IFO $15268^{\mathrm{T}}$; 3 , Kineococcus radiotolerans ATCC BAA- $149^{\mathrm{T}}$. +, Positive; -, negative; ND, not determined. Data for reference strains were taken from Yokota et al. (1993) and Phillips et al. (2002).

\begin{tabular}{|c|c|c|c|}
\hline Characteristic & 1 & 2 & 3 \\
\hline \multicolumn{4}{|l|}{ Utilization of: } \\
\hline D-Galactose & + & - & + \\
\hline D-Lactose & + & $\mathrm{ND}$ & - \\
\hline Maltose & + & - & - \\
\hline D-Mannose & + & - & + \\
\hline Raffinose & + & - & - \\
\hline L-Rhamnose & + & - & - \\
\hline D-Ribose & + & - & - \\
\hline D-Trehalose & + & - & ND \\
\hline Glycerol & + & - & + \\
\hline Mannitol & + & - & + \\
\hline Inositol & + & - & + \\
\hline Urease activity & - & + & - \\
\hline \multicolumn{4}{|l|}{ Hydrolysis of: } \\
\hline Aesculin & + & - & ND \\
\hline Gelatin & + & - & ND \\
\hline Starch & + & - & $\mathrm{ND}$ \\
\hline $\begin{array}{l}\text { Temperature range for } \\
\text { growth }\left({ }^{\circ} \mathrm{C}\right)\end{array}$ & $4-37$ & $9-36$ & $11-41$ \\
\hline $\mathrm{pH}$ range for growth & $5 \cdot 1-10 \cdot 1$ & $6 \cdot 0-9 \cdot 0$ & $5 \cdot 0-9 \cdot 0$ \\
\hline Growth on $7 \% \mathrm{NaCl}$ & + & - & $\mathrm{ND}$ \\
\hline
\end{tabular}

diamino acid of peptidoglycan, major menaquinone, phospholipid composition and fatty acid profiles). The genera Kineococcus and Kineosporia are readily differentiated from each other on the basis of morphological and chemical features (Yokota et al., 1993; Itoh et al., 1989; Kudo et al., 1998). It was evident from the phenotypic and genetic data presented that the isolate belonged to the genus Kineococcus, but represented a novel species within the genus, for which the name Kineococcus marinus sp. nov. is proposed.

\section{Description of Kineococcus marinus sp. nov.}

Kineococcus marinus (ma.ri'nus. L. masc. adj. marinus of the sea, the origin of the sample from which the type strain was isolated).

Aerobic, motile, non-spore-forming, oxidase-negative, catalase-positive, Gram-positive cocci. Cells occur singly, in pairs or in clusters. Forms capsular polysaccharide-like substances on most solid media. Colonies are circular, smooth, convex and deep orange in colour. Glucose fermentation, $\mathrm{H}_{2} \mathrm{~S}$ production and nitrate reduction are not observed. The temperature range for growth is $4-37^{\circ} \mathrm{C}$ with an optimum at $30^{\circ} \mathrm{C}$. No growth is observed at or above $40^{\circ} \mathrm{C}$. Growth occurs at $\mathrm{pH} 5 \cdot 1-10 \cdot 1$, with an optimum at $\mathrm{pH} 7 \cdot 1 . \beta$-Galactosidase is present, but urease activity is not detected. DNA, aesculin, gelatin and starch are hydrolysed, but casein and elastin are not. Salt is required for growth; good growth occurs at $1-4 \% \mathrm{NaCl}$, moderate growth at $5-8 \% \mathrm{NaCl}$ and poor growth at $9 \% \mathrm{NaCl}$. $\alpha$-Cyclodextrin, $\beta$-cyclodextrin, dextrin, glycogen, $\mathrm{L}$-arabinose, D-arabitol, arbutin, D-cellobiose, D-fructose, L-fucose, D-galactose, Dgalacturonic acid, gentiobiose, D-gluconic acid, $\alpha$-D-glucose, myo-inositol, $\alpha$-D-lactose, lactulose, maltose, D-mannitol, D-mannose, D-melezitose, methyl $\beta$-D-galactoside, 3-methyl D-glucoside, methyl $\alpha$-D-glucoside, methyl $\alpha$-D-mannoside, palatinose, D-psicose, D-raffinose, L-rhamnose, D-ribose, salicin, sedoheptulosan, stachyose, sucrose, D-tagatose, D-trehalose, turanose, xylitol, D-xylose, acetic acid, $\alpha$ - and $\beta$-hydroxybutyric acids, $p$-hydroxyphenylacetic acid, $\alpha$-ketoglutaric acid, $\alpha$-ketovaleric acid, lactamide, L-lactic acid, D- and L-malic acid, monomethyl succinate, propionic acid, succinamic acid, L-alaninamide, D- and L-alanine, L-asparagine, glycyl L-glutamic acid, L-serine, glycerol, adenosine, 2'-deoxyadenosine, inosine, adenosine 5'monophosphate, thymidine $5^{\prime}$-monophosphate, uridine $5^{\prime}$-monophosphate, D-fructose 6-phosphate, $\alpha$-D-glucose 1 -phosphate and DL- $\alpha$-glycerol phosphate are utilized as sole carbon and energy sources for growth. The following substrates are not utilized: inulin, mannan, Tweens 40 and $80, N$-acetyl-D-glucosamine, $N$-acetyl- $\beta$-D-mannosamine, amygdalin, maltotriose, D-melibiose, methyl $\alpha$-D-galactoside, methyl $\beta$-D-glucoside, D-sorbitol, $\gamma$-hydroxybutyric acid, D-lactic acid methyl ester, methyl pyruvate, succinic acid, $\mathrm{N}$-acetyl-L-glutamic acid, L-alanyl glycine, L-glutamic acid, L-pyroglutamic acid, putrescine, 2,3-butanediol, thymidine, uridine and D-glucose 6-phosphate. The diagnostic diamino acid of the peptidoglycan is meso-diaminopimelic acid. Whole-cell hydrolysates contain arabinose and galactose as characteristic sugars. The glycan moiety of the murein structure is acetylated. Mycolic acids are not detected. The predominant menaquinone is MK-9 $\left(\mathrm{H}_{2}\right)$. Polar lipid contains phosphatidylglycerol and phosphatidylinositol (phospholipid-type PI pattern sensu Lechevalier et al., 1981). The major cellular fatty acid is 12-methyltetradecanoic acid (anteiso- $\mathrm{C}_{15: 0}$ ). The $\mathrm{G}+\mathrm{C}$ content of the DNA is $76 \cdot 6 \mathrm{~mol} \%$.

The type strain, KST3- $3^{\mathrm{T}}\left(=\mathrm{KCCM} 42250^{\mathrm{T}}=\right.$ NRRL B$24439^{\mathrm{T}}$ ), was isolated from a sediment sample of the coast of Jeju, Republic of Korea.

\section{Acknowledgements}

This work was supported by the 21C Frontier Microbial Genomics and Application Center Program, Ministry of Science \& Technology, Republic of Korea.

\section{References}

Brosius, J., Palmer, J. L., Kennedy, J. P. \& Noller, H. F. (1978). Complete nucleotide sequence of a $16 \mathrm{~S}$ ribosomal RNA gene from Escherichia coli. Proc Natl Acad Sci U S A 75, 4801-4480.

Felsenstein, J. (1981). Evolutionary trees from DNA sequences: a maximum likelihood approach. J Mol Evol 17, 368-376. 
Felsenstein, J. (1993). PHYLIP - Phylogeny Inference Package, version 3.51c. Distributed by the author. Department of Genome Sciences, University of Washington, Seattle, USA.

Fitch, W. M. (1971). Toward defining the course of evolution: minimum change for a specific tree topology. Syst Zool 20, 406-416.

Gordon, R. E., Barnett, D. A., Handerhan, J. E. \& Pang, C. H.-N. (1974). Nocardia coeliaca, Nocardia autotrophica, and the nocardin strain. Int J Syst Bacteriol 24, 54-63.

Itoh, T., Kudo, T., Parenti, F. \& Aeino, A. (1989). Amended description of the genus Kineosporia, based on chemotaxonomic and morphological studies. Int J Syst Bacteriol 39, 168-173.

Jukes, T. H. \& Cantor, C. R. (1969). Evolution of protein molecules. In Mammalian Protein Metabolism, pp. 21-132. Edited by H. N. Munro. New York: Academic Press.

Kroppenstedt, R. M. (1985). Fatty acid and menaquinone analysis of actinomycetes and related organisms. In Chemical Methods in Bacterial Systematics, pp. 173-199. Edited by M. Goodfellow \& D. E. Minnikin. London: Academic Press.

Kudo, T., Matushima, K., Itoh, T., Sasaki, J. \& Suzuki, K. (1998). Description of four new species of the genus Kineosporia: Kineosporia succinea sp. nov., Kineosporia rhizophila sp. nov., Kineosporia mikuniensis sp. nov., Kineosporia rhamnosa sp. nov., isolated from plant samples, and amended description of the genus Kineosporia. Int J Syst Bacteriol 48, 1245-1255.

Lechevalier, M. P., Stern, A. E. \& Lechevalier, H. A. (1981). Phospholipids in the taxonomy of actinomycetes. Zentralbl Bakteriol Hyg Abt 1 Suppl 11, 111-116.

Lee, S. D., Kang, S.-O. \& Hah, Y. C. (2000). Hongia gen. nov., a new genus of the order Actinomycetales. Int J Syst Evol Microbiol 50, 191-199.

MacFaddin, J. F. (1980). Biochemical Tests for Identification of Medical Bacteria, 2nd edn. Baltimore: Williams \& Wilkins.

Mesbah, M., Premachandran, U. \& Whitman, W. B. (1989). Precise measurement of the $\mathrm{G}+\mathrm{C}$ content of deoxyribonucleic acid by high-performance liquid chromatography. Int J Syst Bacteriol 39, 159-167.
Minnikin, D. E., Patel, P. V., Alshamaony, L. \& Goodfellow, M. (1977). Polar lipid composition in the classification of Nocardia and related bacteria. Int J Syst Bacteriol 27, 104-117.

Minnikin, D. E., Hutchinson, I. G., Caldicott, A. B. \& Goodfellow, M. (1980). Thin layer chromatography of methanolysates of mycolic acid-containing bacteria. J Chromatogr 188, 221-233.

Minnikin, D. E., O’Donnell, A. G., Goodfellow, M., Alderson, G., Athalye, M., Schaal, A. \& Parlett, J. H. (1984). An integrated procedure for the extraction of bacterial isoprenoid quinones and polar lipids. J Microbiol Methods 2, 233-241.

Phillips, R. T., Wiegel, J., Berry, C. J., Filermans, C., Peacock, A. D., White, D. C. \& Shimkets, L. J. (2002). Kineococcus radiotolerans sp. nov., a radiation-resistant, Gram-positive bacterium. Int $J$ Syst Evol Microbiol 52, 933-938.

Saddler, G. S., Tavecchia, P., Lociuro, S., Zanol, M., Colombo, E. \& Selva, E. (1991). Analysis of madurose and other actinomycete whole cell sugars by gas chromatography. J Microbiol Methods 14, 185-191.

Saitou, N. \& Nei, M. (1987). The neighbor-joining method: a new method for reconstructing phylogenetic trees. Mol Biol Evol 4, 406-425.

Stackebrandt, E., Rainey, F. A. \& Ward-Rainey, N. L. (1997). Proposal for a new hierarchic classification system, Actinobacteria classis nov. Int J Syst Bacteriol 47, 479-491.

Staneck, J. L. \& Roberts, G. D. (1974). Simplified approach to identification of aerobic actinomycetes by thin-layer chromatography. Appl Microbiol 28, 226-231.

Thompson, J. D., Gibson, T. J., Plewniak, F., Jeanmougin, F. \& Higgins, D. G. (1997). The CLUSTAL_X windows interface: flexible strategies for multiple sequence alignment aided by quality analysis tools. Nucleic Acids Res 25, 4876-4882.

Uchida, K. \& Aida, K. (1984). An improved method for the glycolate test for simple identification of the acyl type of bacterial cell walls. J Gen Appl Microbiol 30, 131-134.

Yokota, A., Tamura, T., Nishii, T. \& Hasegawa, T. (1993). Kineococcus aurantiacus gen. nov., sp. nov., a new aerobic, gram-positive, motile coccus with meso-diaminopimelic acid and arabinogalactan in the cell wall. Int J Syst Bacteriol 43, 52-57. 